\title{
Felsefe Grubu Öğrencilerinin Akademik Motivasyonları İle Sorgulama Becerileri Arasındaki İlişsinin İncelenmesi
}

\author{
The Investigation of The Relationship Between Academıc \\ Motivations And Inquiry Skills of Philosophy Students
}

\author{
Gamze TUNCER*, Tuğba YANPAR YELKEN**, Iş11 TANRISEVEN***
}

\begin{abstract}
Öz: $\mathrm{Bu}$ araştırma ile Felsefe grubu öğrencilerinin akademik motivasyonları ile sorgulama becerileri arasındaki ilişkinin çeşitli değişkenlere göre incelenmesi amaçlanmıştır. Araştırmada, tarama yöntemlerinden ilişkisel tarama yöntemi kullanılmıştır. Araştırmanın örneklemini 2016-2017 eğitimöğretim yılında, bir devlet üniversitesinde öğrenim gören 4. Sinıfa devam eden 73 Felsefe bölümü öğrencisi ve aynı üniversitede formasyon eğitimi alan 11 Felsefe bölümü mezunu ve 49 Sosyoloji bölümü mezunu olmak üzere toplam 133 öğretmen adayı oluşturmuştur. Araştırmada veri toplama aracı olarak, Vallerand ve diğerleri (1992) tarafından geliştirilmiş, Karataş ve Erden (2011) tarafindan geçerlik güvenirlik çalışması ile kültürel adaptasyonu yapılan Akademik Motivasyon Ölçeği kullanılmıştır. Akademik Motivasyon Ölçeği (AMÖ) 28 maddeden oluşmaktadır. AMÖ motivasyonsuzluk, dışsal motivasyon ve içsel motivasyon olmak üzere üç temel boyuttan oluşan yedili likert tipli bir ölçektir. Ayrıca araştırmada kullanılan diğer bir veri toplama aracı, Karademir (2013) tarafından geliştirilen Sorgulama Becerileri Ölçeği'dir. Ölçek 14 maddeden ve 3 alt boyuttan (Bilgi Edinme, Bilgiyi Kontrol Etme, Özgüven) oluşan beşli likert tipli bir ölçektir. Araştırma sonucuna göre Felsefe grubu öğrencilerinin akademik motivasyon ve sorgulama becerisi düzeylerinin "iyi” düzeyde olduğu tespit edilmiştir. Felsefe grubu öğrencilerinin akademik motivasyonları ile sorgulama becerileri arasında anlamlı bir ilişki bulunmuştur. Felsefe grubu öğrencilerinin akademik motivasyon ve sorgulama becerisi düzeyleri arasında cinsiyet, mezun olma, bölüm ve yaş değişkenlerine göre anlamlı bir farklılık göstermezken sorgulama becerisi düzeyleri arasında yaş değişkenine göre anlamlı bir farklılık gösterdiği tespit edilmiştir.

Anahtar Kelimeler: Motivasyon, akademik motivasyon, sorgulama becerisi, felsefe grubu öğrencileri
\end{abstract}

\begin{abstract}
The aim of this study is to investigate the relationship between academic motivation and inquiry skills of Philosophy students. In the study, relational survey method was used. The sample of the study was composed a total of 133 pre-service teachers, 73 of which were studying in a public university, and 11 with a degree in Philosophy and 49 with a degree in sociology in the 2016-2017 academic year. The data were collected with Academic Motivation Scale which was developed by Vallerand et al. (1992). The validity and reliability of the scale and its cultural adaptation to Turkish were made by Karataş and Erden (2011). Academic Motivation Scale (AMO) consists of 28 items. AMC is a sevenpoint Likert type scale consisting of three main dimensions: motivation, extrinsic motivation and intrinsic motivation. In addition, another data collection tool used in the research is the Inquiry Skills Scale developed by Karademir (2013). The scale is a 5-point Likert-type scale consisting of 14 items and 3 subdimensions (Information Acquisition, Information Control, Self-Confidence). According to the results of the research, it was found that the academic motivation and questioning skill levels of the students of Philosophy were good. A significant relationship was found between the academic motivation and inquiry skills of the students of Philosophy group. While there is no significant difference between the academic
\end{abstract}

\footnotetext{
* Bu çalışma, 2. Uluslararası Çağdaş Eğitim Araştırmaları Kongresin'de bildiri olarak sunulmuştur.

** Yüksek Lisans Öğrencisi, Mersin Üniversitesi, Eğitim Fakültesi, Mersin, Türkiye, ORCID: 0000-0003-2129-2682 e-posta: tuncer.gamzee@gmail.com

*** Prof. Dr., Mersin Üniversitesi, Eğitim Fakültesi, Mersin, Türkiye, ORCID: 0000-0002-0800-4802 e-posta: tyanpar@gmail.com

*** Doç. Dr., Mersin Üniversitesi, Eğitim Fakültesi, Mersin, Türkiye, ORCID: 0000-0001-5884-2807 e-posta: isiltanriseven77@gmail.com
} 
motivation and inquiry skill levels of the students in the Philosophy group according to the gender, class, department and age variables, it has been found that there is a significant difference between the inquiry skill levels according to age variable.

Keywords: Motivation, academic motivation, inquiry skill, pre-service, philosophy teacher

Giriş

Öğrencilerin akademik yaşantılarında başarı ve öğrenmelerini etkileyen çeşitli faktörler vardır. $\mathrm{Bu}$ faktörlerden biri de motivasyondur. Motivasyon eğitimin her kademesinde, öğrencinin başarısını doğrudan etkileyen bir faktördür. Motive edilmiş öğrenciler okul performanslarında ve derslerinde başarı sağlamada motive edilmemiş öğrencilere göre daha avantajlı olduğu kesinlikle yadsınamaz bir gerçektir. Birçok eğitimci öğrencilerin akademik başarılarında motivasyonun önemli rol oynadığını kabul etmektedir (Karataş, 2011).

Günümüzde pek çok eğitimci ve kuramcının kendi motivasyon tanımı mevcuttur. Luthans'a (1995) göre motivasyon kavramı; psikolojik ve fiziksel bir eksiklikten kaynaklı olarak başlayan sürecin davranışı veya dürtüyü harekete geçirmesidir. "Eren (2012), bir insanı belirli bir amaç için harekete geçiren güç olarak" (s. 498) ve "Aydın (2004) tarafından ise, bir davranışı başlatan ve bu davranışın yön ve sürekliliğini belirleyen içsel (bireye ait) bir güç, (s. 199) şeklinde tanımlanmıştır." Diğer bir tanıma göre ise motivasyon belirli bir eylemi yerine getirmek için bireyin içsel ve dışsal etkenlerden güç alması, aldığı bu güç ile davranışlarında kararllı1ık göstermesi ve davranışlarını yönetmesidir (Barutçugil, 2004).

Motivasyonun, başarıyı ve öğrenmeyi olumlu yönde etkileyen bir yanı olduğu gibi başarılı performanslar sergilemeye yardımcı olan ve etkinliklere de ilgi uyandıran bir rolü vardır (Schunk, Pintrich ve Meece, 2008). Bunun yanısıra Motivasyon yüksek düzeyden, düşük düzeye doğru giden bir öz belirleme yapısına sahiptir (Vallerand ve diğerleri 1993).

Literatürde motivasyonu açıklamaya yönelik pek çok kuram ve yaklaşım mevcuttur. Bu kuramlar arasında bilişsel temellere dayanan diğer bir kuramda "özerklik belirleme kuramıdır." $\mathrm{Bu}$ kuram diğer kuramların aksine motivasyonel davranışlar hakkında daha kapsamlı açıklamamlarda bulunmaktadır. Ayrıca motivasyonda davranışın nedenine odaklanarak, motivasyonlu davranışın tamamen bireyin kendi isteğine bağlı olarak öz-belirlenmişliğine veya kişinin kendi içinde bulunan zorlamalara dayandığını savunmaktadır (Deci ve diğerleri, 1991). "Özerklik Belirleme Kuramı, insanın kişilik gelişimi ve davranışsal öz düzenleme için insanların gelişmiş içsel kaynaklarının önemini vurgulayan, insan motivasyonuna ve kişiliğine yönelik bir yaklaşımdır" (Ryan, Kuhl ve Deci, 1997). Diğer bir açılamaya göre Özerklik Belirleme Kuramı, farklı motivasyon türlerini ve onların psikolojik fonksiyonlarını (öğrenme, performans) değerlendirmektedir (Deci ve Ryan, 1985). Dolayısıla bu kuram bireylerin doğuştan gelen psikolojik ve sosyal ilişkilerdeki ihtiyaçlarının dikkate alınmasını ve doyurulması gerektiğini savunur. $\mathrm{Bu}$ ihtiyaçların engellenmesi bireyin motivasyonun zayıflamasına, performansının düşmesine ve psikolojik durumunun olumsuz etkilenmesine neden olur (Deci ve Ryan, 2000).

Deci ve Ryan (2000) özerklik belirleme kuramından yola çıkarak motivasyon türlerini üç genel kategoride sıralamıştır. Bunlar; içsel motivasyon, dışsal motivasyon ve motivasyonsuzluktur. En genel anlamda içsel motivasyon; kişinin davranışını düzenleyen dışsal bir kontrol olmaksızın işin kendisi tarafından motive edilmesidir. İçsel motivasyon bireyin içsel ihtiyaçlarına yönelik tepkilerdir. Merak, bilme, yeterli olma ihtiyacı, gelişme ve başarma arzusu içsel güdülere örnek gösterilebilir. Diğer bir deyişle bir şeyin kişiye sadece zevk verdiği veya ilginç geldiği için yapıldığı motivasyon türüdür. Dışsal motivasyon, bireyin çevresinden gelen etkileri içerir. Bir çalışanın performansından dolayı ücret alması, ikramiyeler, terfi etmesi ve yönetici tarafından taktir edilmesi gibi ödüller dışsal motivasyona örnek verilebilir. Dışsal motivasyon, içsel motivasyonun tersine, ödül odaklıdır. Birşeyi elde etmek için yapılan aktiviteden zevk almak yerine, faydalara odaklanan motivasyon türüdür (Ersarı ve Naktiyok, 2012).

Son olarak motivasyonsuzluk ise (amotivasyonsuzluk) motive olma bir eylemi gerçekleştirmek için harekete geçirilme anlamına gelmesine karşın motivasyonsuzluk harekete 
geçmek için niyet eksikliği durumu olarak tanımlanmaktadır (Deci ve Ryan, 2000). Başka bir tanıma göre motivasyonsuzluk, harekette bulunma isteğinden yoksun olma durumu olarak adlandırılmaktadır. Bireyler çıktılar ve kendi davranışları arasında olumlu bir durum algılamadıklarında motivasyonsuz olurlar. Başka bir deyiş̧le, ne içsel ne de dışsal olarak motive olmazlar (Karataş, 2011).

Dünyanın her yerindeki eğitim sistemlerinin temel hedefi, eğitimin her kademesindeki öğrencilerin akademik başarısını arttırmaktır. Bu hedefi gerçekleştirmenin yolu, kişilerin sosyal ve psikolojik ihtiyaçlarının doyurulmasıdır. $\mathrm{Bu}$ temel ihtiyaçların doyurulması halinde öğrenciler akademik performanslarını sağlıklı bir şekilde arttırabilir ve öğrenme ortamını doğrudan ve olumlu bir şekilde etkiliye bilirler (Karataş, 2011).

Öğrencilerin bu şekilde sağlklı bir performans gösterebilmeleri için, öğrenme ortamlarında öğretmenlerin motivasyonun önemini unutmamaları gerekir. Yeterli motivasyon olmaksızın bireyler dikkate değer becerileri, uygun müfredatları ve iyi öğretmenleri olmasına rağmen uzun dönem amaçlarına ulaşamazlar (Dörnyei, 1998). Akademik motivasyon öğrencilerin önceden belirledikleri hedeflere ulaşmak için duydukları isteklilik hali olarak tanımlanmaktadır (Wilkesmam ve diğerleri, 2012). Akademik motivasyonu etkileyen çeşitli faktörler bulunmaktadır. Bunlar; yeniliğe açık öğrenciler, okul dışında sahip oldukları çalışma ortamı, ders çalışma süresi, öğrencilerin çalışma geçmişi, yaşadıkları çevre koşulları ve öğrenci ihtiyaçları olarak sıralanabilir (Wilkesmam ve diğerleri, 2012). Tüm bunlar sonucunda akademik motivasyon, derse ilişkin olumlu tutum geliştirmede, okul performansı arttırmada ve öğrenme üzerinde olumlu etkiye sahiptir.

Akademik motivasyonla ilişkili olduğu düşünülen ve akademik başarıyı olumlu yönde etkileyen diğer bir belirleyici sorgulama beceriside bu araştırmaya konu olmuştur (Akça, 2014; Arseven, Dervişoğlu ve Arseven, 2015; Babadoğan ve Gürkan, 2002; Emir, Hüner ve Uzelli, 2012; İlter, 2013). Sorgulama, bir beceri olarak ortak temel beceriler arasinda yer alır. Kelime anlamı ise "Bir konuyu sorular sorup yanıtlar vererek araştırma" olarak tanımlanmaktadır (TDK, 2017). Sorgulamayı, kişilerin bir deneyimi, anlamlı duruma getirmek için yaşadığı entelektüel bir süreç olarak gören Beyer'e (1971) göre başarılı bir sorgulayıcının özellikleri arasında, kendisini güdüleyen, yönlendiren ve kendi içinde sorgulamayı sürekli kılmasını sağlayan, şüphecilik; sunulan her şeyi kabul etmeyip yargilamada isteklilik, merak; bilmeyi isteme, nedenlere saygi duyma; yeterli bir kanıtın benimsenebilmesi için zamana gereksinim olduğunu anlama yer almaktadır (Beyer, 1971, Akt. Karademir, 2013).

İnsanlarda sorgulama temelli bir yaklaşımın etkililiği, eğitimin her kademesindeki her tür öğretmenin ve her tür öğrencinin bu yaklaşımı özümsemesi ve bunu hayatının her alanında uygulaması ile mümkündür. Günümüz eğitim anlayışında, bilgiyi depolayan, ezberleyen değil; bilgiyi üreten, kendi fikirlerini uygun bir dille ifade edebilen, doğru ve anlamlı sorular sorarak problemi farkeden, var olan problemleri sorgulayan, problemin çözümü hakkında farklı fikirler suna bilen, bu çözüm yollarını yorumlaya bilen, analiz eden, günlük hayatla ilişkilendirebilen, yeri geldiğinde ekip çalışması yapabilen insan niteliklerine ulaşılmak istenmektedir. Kısacası bu nitelikler incelendiğinde eğitimin her kademesindeki her tür öğretmenin temel sorgulama becerisine sahip olması ve ögretimin her aşamasında öğrencilerine bu beceriyi kazandırması gerekmektedir. Çünkü sorgulama öğrencilerin hayatları boyunca her alanda daima gereksinim duyacakları temel bir beceri türüdür (Karataş, 2011).

"Öğrencilere kazandırılmak istenen temel düşünme becerilerinden olan sorgulama becerisi ise, doğru ve anlamlı sorular sorarak problemi fark etme ve kavrama, problemi çözmek amacıyla neyi ve nasıl yapması ile ilgili araştırma planlaması yapma, sonuçları tahmin etme, çıkabilecek sorunları göz önüne alma, sonucu test etme ve fikirleri geliştirmeyi kapsamaktadır” (MEB, 2004, s. 735). Bu şekilde öğrenme sürecine katılan öğrenciler, anlamlı tahminde bulunma, uygun araştırma ortamına karar verme, araştırmada ne tip ve ne kadar delil toplaması gerektiğine karar verme, bilimsel yaklaşımı kullanarak araştırmayı planlama, nasıl gözlem ve kıyas yapacağını belirleme, araç gereç kullanma, doğru ve hassas ölçümler yapabilme, sonuçları sunma yollarını belirleme, sonuçların tekrar incelenmesi gerekip gerekmediğine karar verme, bulunanlarla asıl fikrin bağlantısını kurma, bulunanları uygun 
bir dille ifade etme, verileri ortaya koyma sonucu destekleyici verilerin yeterliliğine karar verme, bulunanların ilk beklentileri karşılayıp karşılamadığına karar verme gibi sorgulama becerisinin alt becerilerine sahip olurlar (MEB, 2004, s. 735). Suchman'a göre; sorgulama becerisini kazanmış ve sorgulayarak öğrenenler, öğrenme süreci içerisinde daha etkili bir konuma sahiptirler. Bununla birlikte bilgiyi yorumlamada ve aldıkları kararlarda sorumluluk sahibi bir tavır sergilemektedirler. Bu şekilde öğrenme eylemini gerçekleştirenler daha anlamlı ve motivasyonel öğrenenlerdir (Costa, 1991).

Milli Eğitim Bakanlığı tarafından geliştirilen yeni öğretim programlarında temel düşünme becerilerinden olan sorgulama becerisi, çoğunlukla araştırma-sorgulama becerisi olarak adlandırılmaktadır (Karademir, 2013). Babadoğan ve Gürkan'a (2002) göre "sorgulama tabanlı öğretim" sorgulayıcı öğretim stratejisi olarak adlandırılmaktadır. Sorgulayıcı öğretim ise, öğretmenle öğrenci arasındaki sürece araştırma boyutunun eklenmesidir.

Stephenson (2010) sorgulama tabanlı öğrenmenin birçok öğrenme ve öğretme yaklaşımını kapsadığını ileri sürmüştür. Bu görüşe dayalı olarak sorgulama tabanlı öğretimde kullanılan birtakım öğretim uygulamaları vardır. Kullanılan bu öğretim uygulamaları; 1. Problem tabanlı öğrenme: Öğrenme, öğrenenleri ilgilendiren soruları, problemleri ya da bir vaka çalışmasını araştırmayla başlar. 2. Proje tabanlı öğrenme: Öğrenenler anladıklarını göstermek için araştırma çabasına girerek bir proje ya da sunum oluştururlar. 3. Tasarım tabanlı öğrenme: Karmaşık bir durum ya da problemin tasarım çalışmasıyla planlı ve belirgin hale getirerek çözmeyi öğrenmek (Stephenson, 2010). Stripling (2008) ise, sorgulayıc1 araştırma modeli öğrenme modelini, 1. Merak, 2. Soruşturma, 3. Yapılandırma, 4. Açıklama, 5. Yansıtma, 6. İlişkilendirme olarak altı aşamada incelemektedir. Öğretmenler, ders esnasında öğrencilere bu aşamaları tekrar ettirmek veya onları bu aşamalara tekrar yönlendirmek için öğrencileri istekli hale getirir. Çünkü sorgulayıcı araştırma, öğrencilerin kavramsal anlayışının gelişimine yardımcı olurken, aynı zamanda öğrencilerin yaşamlarını içerikle ilişkilendirmelerine fırsat tanıyan bir öğrenme modelidir (Stripling, 2008).

Son yıllarda, alan yazınında gerek akademik motivasyon (Clark ve Schroth, 2010; Demir ve Arı, 2013; Rienties ve diğerleri, 2009) gerekse sorgulama becerisinin (Babadoğan ve Gürkan, 2002; Balım, İnel ve Evrekli, 2008; Bedir ve Duman, 2017; Dibiase ve Mcdonald, 2015; Engin 2009; Güngör \& Seyhan, 2008; Kızılarslan, 2014; Şen, 2010; Yılmaz ve Karamustafaoğlu 2015; Zhu ve Geelan, 2013) okul performansındaki önemi, öğrencilerin akademik başarıları, derse yönelik tutumları, bilimsel süreç becerileri ve diğer değişkenlerin öğrenme üzerindeki olumlu etkisi birçok araştırmayla ortaya konulmuştur. Bu çalışmalara örnek olarak; Rienties ve diğerleri (2009) yaptıkları çalışmada öğrencilerin bilgisayar destekli işbirlikli öğrenmelerinde motivasyonun rolü araştırmışlardır. Araştırma sonucunda öğrenciler arasında sözel ifadelerin türü ve miktarı bakımından farklılıklar olduğu tespit edilmiştir. İçsel motivasyona sahip öğrencilerin bilişsel söylemlere daha fazla katkı sağladığı görülmektedir. İçsel motivasyon düzeyleri yüksek öğrencilerin sosyal ağdaki konumu oldukça yön vericidir. Bunun aksine dışsal motivasyona sahip olan öğrencilerin sözel söylemlere katkısı orta derecede olduğu tespit edilmiştir. Özetle; akademik motivasyondaki farkl1lıkların öğrencilerin sosyal ağdaki konumunu ve sözel ifadeye katkısını oldukça etkilemektedir. Demir ve Arı (2013) İlköğretim Bölümü öğretmen adaylarının akademik güdülerini ortaya koymayı amaçladıkları çalışmanın sonucunda ilköğretim öğretmen adaylarının akademik güdülenme düzeylerinin cinsiyet, öğretim türü, aile geliri, anne ve baba eğitim durumu, bir yılda okunan kitap sayısı değişkenlerine göre anlamlı bir farklılık göstermediği tespit edilmiştir. Ancak öğretmen adaylarının akademik güdülenme düzeyleri anabilimdalına göre anlamlı bir farklılık göstermektedir. Sorgulama becerisine yönelik çalışmalara örnek olarak ise; Dibiase ve Mcdonald (2015) fen bilgisi öğretmenlerinin sorgulamaya dayalı öğrenmeye ilişkin tutumlarını, değerlerini ve inançlarını belirlemeyi amaçladığı çalışmanın sonucunda öğretmenlerin sorgulamaya dayalı öğretim etkinliklerinin uygulanmasında eksikliklerin olduğu ve bu eksikliklerin giderilip ona uygun olarak düzenlenmesi gerektiği tespit edilmiştir. Benzer şekilde Engin'in (2009) Türk ve Hollandalı sınıf öğretmeni adaylarının sorgulama yaklaşımına ilişkin algılarını karşılaştırdığı çalışmasının sonucunda öğretmen adayları, derslerde sorgulama 
yaklaşımını önemli bulmakta ve bu konuda yeterli donanıma sahip olduklarını düşünmektedirler. Türk ve Hollandalı sınıf öğretmeni adaylarının sorgulama yaklaşımına ait bilgilerine güven dereceleri ölçüldüğünde, Türk öğretmen adayları kendi bilgilerine daha çok güvendikleri tespit edilmiştir.

Alan yazınına bakıldığında bu iki değişkenin bir arada ele alınarak incelendiği bir araştırma ile karşılaşılmamıştır. Bu nedenle bu çalışmada, birbirlerinin anlamlı bir biçimde etkilediği düşünülen bu iki değişkenin birlikte ele alınarak incelenmesinin oldukça anlamlı olacağ 1 düşüncesinden hareketle felsefe grubu öğrencilerinin akademik motivasyonlarındaki değişikliğin, sorgulama becerilerini nasıl etkilediğini gözler önüne sermek açısından oldukça önemli olduğu düşünülmektedir. Ayrıca bu çalışma öğrencilerin sahip olduğu akademik motivasyon türleri ve seviyelerinin belirlenerek, sorgulama becerilerinin gelişmesine engel olan eksikliklerin giderilebilmesi ve bu eksikliklere yönelik öneriler getirilmesi açısından da oldukça önemlidir. Bu çalışmanın sonucunda elde edilen veriler daha sonraki araştırmalara 1 şık tutacaktır.

Araştırmada Felsefe grubu öğrencilerinin akademik motivasyonları ile sorgulama becerileri arasındaki ilişkinin çeşitli değişkenlere göre incelenmesi amaçlanmıştır. $\mathrm{Bu}$ genel amaç doğrultusunda aşağıdaki sorulara cevap aranmıştır.

1. Felsefe grubu öğrencilerinin, sorgulama becerileri nasıldır?

2. Felsefe grubu öğrencilerinin, akademik motivasyonları nasıldır?

3. Felsefe grubu öğrencilerinin, akademik motivasyonları ile sorgulama becerileri arasında anlamlı bir ilişki var mıdır?

4. Felsefe grubu öğrencilerinin, akademik motivasyonları çeşitli değişkenlere (cinsiyet, mezun olma, bölüm, yaş) göre anlamlı bir farklılık göstermekte midir?

5. Felsefe grubu öğrencilerinin, sorgulama becerileri çeşitli değişkenlere ( cinsiyet, mezun olma, bölüm, yaş,) göre anlamlı bir farklılık göstermekte midir?

\section{Yöntem}

Betimsel nitelikte olan bu araştırmada, Felsefe grubu öğrencilerinin, akademik motivasyonları ile sorgulama becerileri arasındaki ilişkiyi belirlemek amacıyla tarama modellerinden ilişkisel tarama modeli kullanılmıştır. İlişkisel (korelasyon) tarama modelleri, iki ve daha çok sayıdaki değişken arasında birlikte değişim varlığını ve veya derecesini belirlemeyi amaçlayan araştırma modelleridir (Karasar, 2003). Fraenkel ve Wallen (2009) ise ilişkisel araştırmaları, iki veya daha fazla değişken arasındaki ilişkinin derecesini ortaya koyan araştırma türü olarak tanımlamaktadır.

\section{Evren ve örneklem}

Araştırmada ulaşılabilir evren kullanılmıştır. Ulaşılabilir evren, araştırmacının tercihine bağlı ve ulaşılabilir olan somut evren türüdür (Büyüköztürk ve diğerleri, 2016). Araştırmanın evrenini 2016-2017 öğretim yılında, bir devlet üniversitesinde öğrenim gören 4. sınıf Felsefe bölümü öğrencileri ve Felsefe Grubu Formasyon öğrencileri oluşturmaktadır.

Öğrenim gördükleri bölümün ve dört y1llık eğitim süreçlerinde almış oldukları derslerin sorgulama becerisiyle ilişkili olması, bölüm hakkında yeterli bilgi donanımına sahip olmaları ve de alanlarındaki olumlu ve olumsuz imkânlardan haberdar olmaları bakımından 4. sınıf Felsefe bölümü öğrencileri ve felsefe grubu formasyon öğrencileri araştırmanın örneklemini oluşturmaktadırlar. Ayrıca formasyon eğitimi alarak Felsefe grubu öğretmeni olmaya hak kazanan Sosyoloji bölümü mezunları da araştırmanın Felsefe grubu formasyon öğrencileri arasına dahil edilmiştir. Araştırmanın örnekleminde kolay ulaşılabilir durum örneklemesi yöntemi kullanılmıştır. $\mathrm{Bu}$ örnekleme yöntemi araştırmaya hız ve pratiklik kazandırır. Araştırmacı yakın olan ve ulaşılması kolay olan bir durum seçer (Şimşek ve Yıldırım, 2004). Araştırmanın örneklemine ilişkin bilgiler Tablo 1'de sunulmuştur. 
Tablo 1.

Örnekleme İlişkin Betimsel İstatistikler

\begin{tabular}{llll}
\hline Değişkenler & Kategoriler & f & $\%$ \\
\hline \multirow{3}{*}{ Cinsiyet } & Kadın & 104 & 78,2 \\
& Erkek & 29 & 21,8 \\
Bölüm & Toplam & 133 & 100,0 \\
& Felsefe bölümü & 73 & 54,9 \\
& Felsefe Bölümü Formasyon & 11 & 8,3 \\
& Sosyoloji Bölümü Formasyon & 49 & 36,8 \\
\multirow{5}{*}{ Mezun } & Toplam & 133 & 100,0 \\
Öğrenci olma & Felsefe Bölümü Formasyon & 11 & 8,3 \\
& Sosyoloji Bölümü Formasyon & 49 & 36,8 \\
& Felsefe Bölümü & 73 & 54,9 \\
& Toplam & 133 & 100,0 \\
\hline
\end{tabular}

Tablo 1 incelendiğinde araştırmanın örneklemini, $73(\% 54,9)$ 4. Sinıfa devam eden Felsefe bölümü öğrencisi ve 11 felsefe bölümü mezunu formasyon öğrencisi $(\% 8,3), 49(\% 36,8)$ sosyoloji bölümü mezunu formasyon öğrencisi olmak üzere toplamda 133 [ (104 kadın (\%78,2), 29 erkek $(\% 21,8)]$ felsefe grubu ögrencisi oluşturmaktadır.

\section{Veri toplama araçları}

Araştırmada veri toplamak amacıyla, Vallerand ve diğerleri (1992) tarafından geliştirilmiş, ülkemiz koșullarına adaptasyonu yapılan (Karataş ve Erden, 2011), "Akademik Motivasyon Ölçeğì" kullanılmıştır. Akademik Motivasyon Ölçeği (AMÖ) 28 maddeden oluşmaktadır. AMÖ'i motivasyonsuzluk, dişsal motivasyon ve içsel motivasyon olmak üzere üç temel boyuttan oluşmaktadır. AMÖ'deki maddelerin 4 tanesi motivasyonsuzluk $(5,12,19,26), 12$ maddesi dişsal motivasyon $(1,8,15,22,7,14,21,28,3,10,17,24)$ ve 12 maddesi ise içsel motivasyon $(2,9,16,23,6,13,20,27,4,11,18,25)$ boyutlar1 ile ilgilidir. Derecelendirme, "Hiç Uymuyor" (1), "Biraz Uyuyor" (2, 3), "Orta Derecede Uyuyor" (4), "Çok Uyuyor" (5, 6), "Tam Uyuyor" (7) biçiminde yedili likert formunda düzenlenmiş ve puanlanmıştır. Ölçeğin Cronbach Alfa iç tutarlık katsayısı ölçeğin tamamı için .829, "Motivasyonsuzluk" için .84; "Dışsal Motivasyon" için .83; İçsel Motivasyon için .87'dir (Vallerand ve diğerleri, 1992). Bu çalışma için ölçeğin Cronbach Alfa güvenirlik katsayısı ölçeğin tamamı için .89 olarak hesaplanmıştır.

Ayrıca araştırmada Karademir (2013) tarafından geliştirilen "Sorgulama Becerileri Ölçeği " ve "Kişisel Bilgi Formu” kullanılmıştır. Sorgulama Becerileri Ölçeği (SBÖ) 14 maddeye sahip olup Her zaman= 5 Çoğunlukla $=4$ Ara sıra $=3$ Nadiren= 2 Hiçbir Zaman= 1 arasında değişen 5 dereceli likert tipindedir. Bilgi edinme, Bilgiyi Kontrol Etme ve Özgüven olmak üzere 3 alt faktörden oluşmaktadır. Ölçeğin Cronbach Alfa güvenirlik katsayısı ölçeğin tamamı için .82; "Bilgi Edinme" için .76; "Bilgiyi Kontrol Etme" için .66 ve "Özgüven" için .82'dir (Karademir, 2013). Bu çalışma için ölçeğin Cronbach Alfa güvenirlik katsayısı ölçeğin tamamı için .84 olarak hesaplanmıştır. Araştırmada, araştırmacı tarafindan oluşturulmuş "kişisel bilgi formu" kullanılmıştır. Bu formda katılımcılar hakkında bilgi edinmek adına toplam 6 soru yer almaktadır. Bunlar cinsiyet, mezun olma, yaş, formasyon eğitimi alıp almama durumları, öğrenim görülen anabilim dalı, öğrenim gördüğünüz bölümü tercih etmeniz sizin kararınız mıdır? türün de sorulardır.

\section{Verilerin analizi}

Verilerin analizi aşamasında, uygulanan tüm istatistiksel analizlerde SPSS 22 programı kullanılmıştır. Verilerin normal dağılım gösterip göstermediğini test etmek adına Kolmogorov Simirnov testi uygulanmıştır. Yapılan test sonucunda verilerin normal dağılım gösterdiği belirlenmiş̧tir. Akademik Motivasyon (K-S=0.054; $\mathrm{P}>0.05$ ), Sorgulama becerileri (K.S=0.071; 
p $>0,05)$ elde edilen sonuçlara göre verilerin normal dağılım gösterdiği belirlendiğinden Felsefe grubu öğrencilerinin, sorgulama becerileri nasıldır?, Felsefe grubu öğrencilerinin, akademik motivasyonları nasıldır? sorularına verdikleri cevaplara göre frekans, yüzde ve aritmetik ortalama tabloları oluşturulmuştur. Levene testi sonucuna göre $(\mathrm{F}=.651 ; \mathrm{P}>0.05)$ varyansların eşitliği koşulunun sağlandığı görülmüştür. Bu nedenle Felsefe grubu öğrencilerinin, akademik motivasyonları çeşitli değişkenlere (cinsiyet, mezun olma, yaş, bölüm) göre anlamlı bir farklılık göstermekte midir? ve Felsefe grubu öğrencilerinin, sorgulama becerileri çeşitli değişkenlere (cinsiyet, mezun olma, yaş, bölüm) göre anlamlı bir farklı1ık göstermekte midir? sorularına uygun olarak "bağımsız değişkenler için t-testi" ile ANOVA testi uygulanmıştır. Anlamlılık düzeyi 0,05 olarak kabul edilmiştir. Felsefe grubu öğrencilerinin, akademik motivasyonları ile sorgulama becerileri arasında anlamlı bir ilişki var mıdır? sorusuna göre ise "pearson korelasyon katsayısı" analizi kullanılmıştır. Sorgulama becerileri ölçeğine ilişkin aritmetik ortalamanın değerlendirilmesinde 4.20-5.00 "Her Zaman", 3.40-4.19 "Çoğunlukla", 2.60-3.39 "Ara sira", 1.80, 2.59 "Nadiren", 1.00-1.79 "Hiçbir Zaman" aralıkları kabul edilmiştir. (Tekin, 1996). Akademik Motivasyon ölçeğine ilişkin aritmetik ortalamanın değerlendirilmesinde 7.00-6.11 "Tam uyuyor", 6.10-4.41 "Çok uyuyor", 4.40-3.56 "Orta Derecede Uyuyor", 3.55-1.86 "Biraz Uyuşuyor", 1.85-1.00 "Hiç Uyuşmuyor" aralıkları kabul edilmiştir (Gömleksiz ve Serhatlığlu, 2013).

\section{Bulgular}

$\mathrm{Bu}$ bölümde araştırmanın alt problemlerine cevap aranmış ve araştırmada kullanılan ölçeklere ilişkin istatistiki bilgilere yer verilmiştir.

Felsefe grubu öğrencilerinin, sorgulama becerileri nasıldır alt problemi kapsamında Alt Faktörlere Göre Frekans, Aritmetik Ortalama Ve Standart Sapma sonuçları tablo 2'de sunulmuştur.

Tablo 2.

Felsefe Grubu Öğrencilerinin, Sorgulama Becerilerinin Alt Faktörlere Göre İncelenmesi

\begin{tabular}{lccc}
\hline Faktör & $\mathrm{N}$ & $\overline{\mathrm{X}}$ & Ss. \\
\hline Bilgi Edinme & 130 & 4.10 & 3.05 \\
Bilgiyi Kontrol & 130 & 3.79 & 3.06 \\
Etme & & & \\
Özgüven & 130 & 3.57 & 3.01 \\
Toplam & 130 & 3.87 & 7.25 \\
\hline
\end{tabular}

Tablo 2 incelendiğinde, Felsefe grubu öğrencilerinin bilgi edinme $(\bar{X}=4.10, \mathrm{Ss}=3.05)$ alt faktörüne ve toplam $(\bar{X}=3.87, S s=7.25)$ puana ilişkin ortalamalarının iyi düzeyde olduğu görülmektedir. Ayrıca bilgiyi kontrol etme ( $\bar{X}=3.79, \mathrm{Ss}=3.06)$, özgüven $(\overline{\mathrm{X}}=3.57$, Ss=3.01) alt faktörlerinde ise orta düzeyde olduğu görülmektedir. Bunun yanı sira Felsefe grubu öğrencilerinin bilgi edinme ( $\bar{X}=4.10, S s=3.05)$, bilgiyi kontrol etme $(\bar{X}=3.79, S s=3.06)$, özgüven $(\overline{\mathrm{X}}=3.57, \mathrm{Ss}=3.01)$ alt faktörlerine ve toplam $(\overline{\mathrm{X}}=3.87, \mathrm{Ss}=7.25)$ puana ilişkin görüşlere "çok uyuyor" düzeyinde katıldıkları görülmektedir.

Felsefe grubu öğrencilerinin, akademik motivasyonları nasıldır alt problemi kapsamında Alt boyutlara göre Frekans, Aritmetik Ortalama Ve Standart Sapma Sonuçları tablo 3'te sunulmuştur.

Tablo 3.

Felsefe Grubu Öğrencilerinin, Akademik Motivasyonlarının Alt Faktörlere Göre İncelenmesi

\begin{tabular}{llcl}
\hline Boyut & $\mathrm{N}$ & $\overline{\mathrm{X}}$ & Ss. \\
\hline Motivasyonsuzluk & 130 & 1.87 & 4.74 \\
D1şsal Motivasyon & 130 & 4.81 & 13.67 \\
İsel Motivasyon & 130 & 5.23 & 14.71 \\
Toplam & 130 & 4.57 & 24.67 \\
\hline
\end{tabular}


Tablo 4.

Felsefe Grubu Öğrencilerinin, Akademik Motivasyonları İle Sorgulama Becerileri Arasındaki İlişkinin Korelasyon Katsayısına Göre İncelenmesi

\begin{tabular}{lccc}
\hline Faktörler & Bilgi Edinme & Bilgiyi Kontrol Etme & Özgüven \\
\hline Motivasyonsuzluk & $-.360^{* * *}$ & -.153 & $-.309^{* *}$ \\
Dişsal Motivasyon & $.295^{* *}$ & $.290^{* *}$ & .111 \\
İçsel Motivasyon & $.387^{* *}$ & $.307^{* *}$ & $.279^{* *}$ \\
\hline
\end{tabular}

$\mathrm{N}=130 \mathrm{p}<0,05^{*} \mathrm{p}<0,01^{* *}$

Tablo 4 incelendiğinde, motivasyonsuzluk boyutu ile bilgi edinme $(r=-.360 ; p<0.01)$ ve özgüven $(r=-.309 ; p<0.01)$ faktörleri arasında negatif yönlü düşük düzeyli bir ilişki olduğu görülmektedir. Dişsal motivasyon boyutu ile bilgi edinme $(r=.295 ; \mathrm{p}<0.01)$ ve bilgiyi kontrol etme $(\mathrm{r}=.290 ; \mathrm{p}<0.01)$ faktörleri arasında pozitif yönlü ancak düşük düzeyli bir ilişki olduğu görülmektedir. İçsel motivasyon boyutu ile bilgi edinme $(r=.387 ; \mathrm{p}<0.01)$, bilgiyi kontrol etme $(\mathrm{r}=.307 ; \mathrm{p}<0.01)$ ve özgüven faktörleri arasında ise pozitif yönlü düşük düzeyli bir ilişki olduğu görülmektedir.

Felsefe grubu öğrencilerinin, akademik motivasyonlarının cinsiyet değişkenine göre anlamlı bir farklılık var mıdır alt problemi "ilişkisiz örneklemler için t-testi" sonuçları tablo 5'te sunulmuştur.

Tablo 5.

Felsefe Grubu Öğrencilerinin, Akademik Motivasyonlarının Cinsiyet Değişkenine Göre T- Testi Sonuçları

\begin{tabular}{llllllll}
\hline Boyutlar & Cinsiyet & $\mathrm{N}$ & $\overline{\mathrm{X}}$ & Ss. & $\mathrm{df}$ & $\mathrm{t}$ & $\mathrm{p}$ \\
\hline Motivasyonsuzluk & 1.Kadın & 101 & 7,00 & 7,73 & 128 & $-2,351$ & 0,150 \\
& 2.Erkek & 29 & 9,31 & 8,50 & & & \\
Dışsal Motivasyon & 1.Kadın & 101 & 59,98 & 5,32 & 128 & 3,499 & 0,070 \\
& 2.Erkek & 29 & 50,31 & 6,52 & & & \\
İçsel Motivasyon & 1.Kadın & 101 & 64,42 & 2,58 & 128 & 2,323 & 0,148 \\
& 2.Erkek & 29 & 57,34 & 2,84 & & & \\
Toplam & 1.Kadın & 101 & 131,40 & 10,34 & 128 & 2,853 & 0,286 \\
& 2.Erkek & 29 & 116,96 & 11,75 & & & \\
\hline
\end{tabular}

Tablo 5 incelendiğinde, Felsefe grubu öğrencilerinin akademik motivasyonlarının cinsiyet değişkenine göre motivasyonsuzluk alt boyutunda $\left.\left[\mathrm{t}_{(128)}=-2,351\right) ; \mathrm{p}>0,05\right]$, dişsal motivasyon alt boyutunda $\left.\left[\mathrm{t}_{(128)}=3,499\right) ; \mathrm{p}>0,05\right]$, içsel motivasyon alt boyutunda $\left[\mathrm{t}_{(128)}=\right.$ $2,323) ; \mathrm{p}>0,05]$, ve toplam puanda $\left.\left[\mathrm{t}_{(128)}=2,853\right) ; \mathrm{p}>0,05\right]$ anlamlı bir farklılık göstermediği görülmektedir.

Felsefe grubu öğrencilerinin, Akademik Motivasyonlarının mezun olmadeğişkenine göre anlamlı bir farklılık var mıdır alt problemi kapsamında t-testi sonuçları tablo 6' da sunulmuştur.

Tablo 6.

Felsefe Grubu Öğrencilerinin, Akademik Motivasyonlarının Mezun Olma Değişkenine Göre tTesti Sonuçları

\begin{tabular}{ccrrrrrr}
\hline Boyutlar & Mezun olma & $\mathrm{N}$ & $\overline{\mathrm{X}}$ & Ss. & $\mathrm{df}$ & $\mathrm{t}$ & $\mathrm{p}$ \\
\hline Motivasyonsuzluk & $\begin{array}{c}\text { Ögrenci Olma } \\
\text { (4.sinıf) } \\
\text { Mezun }\end{array}$ & 70 & 8,60 & 5,19 & 128 & 2,962 & 0,002 \\
& & 6,25 & 3,82 & & & \\
\hline
\end{tabular}


Tuncer, Yanpar Yelken ve Tanrıseven

\begin{tabular}{lcllllll}
\hline Dişsal Motivasyon & $\begin{array}{c}\text { Öğrenci olma } \\
(4 . \text { sinıf })\end{array}$ & 70 & 57,41 & 13,96 & 128 & $-0,367$ & 0,619 \\
& $\quad$ Mezun & 60 & 58,30 & 13,43 & & & \\
İçsel Motivasyon & $\begin{array}{c}\text { Öğrenci Olma } \\
\text { (4.sınıf) }\end{array}$ & 70 & 62,35 & 14,76 & 128 & $-0,408$ & 0,784 \\
& $\quad$ Mezun & 60 & 63,41 & 14,75 & & & \\
Toplam & $\begin{array}{c}\text { Oggrenci Olma } \\
\text { (4.sınıf) }\end{array}$ & 70 & 128,37 & 25,14 & 128 & -0.769 & 0,769 \\
& Mezun & 60 & 127,96 & 24,33 & & & \\
\hline
\end{tabular}

Tablo 6 incelendiğinde, Felsefe grubu öğrencilerinin akademik motivasyonlarının mezun olma değişkenine göre dişsal motivasyon alt boyutunda [ $\left.\left.\mathrm{t}_{(128)}=-0,367\right) ; \mathrm{p}>0,05\right]$, içsel motivasyon alt boyutunda $\left.\left[\mathrm{t}_{(128)}=-0,408\right) ; \mathrm{p}>0,05\right]$, ve toplam puanda $\left.\left[\mathrm{t}_{(128)}=-0,769\right) ; \mathrm{p}>0,05\right]$ anlamlı bir farkl11ık göstermediği görülmektedir. Ancak motivasyonsuzluk alt boyutunda $\left[\mathrm{t}_{(128)}=\right.$ 2,962); $\mathrm{p}<0,05]$ mezun olma değişkenine göre 4. Sınıf öğrencilerinin lehine anlamlı bir farklılık olduğu görülmektedir.

Felsefe grubu öğrencilerinin, Akademik Motivasyonlarının Bölüm Değişkenine Göre anlamlı bir farklılık var mıdır alt problemi kapsamında "ANOVA" ve "TUKEY" testi sonuçları tablo 7'de sunulmuştur.

Tablo 7.

Felsefe Grubu Öğrencilerinin, Akademik Motivasyonlarının Bölüm Değişkenine Göre Anova Ve Tukey testi sonuçları

\begin{tabular}{|c|c|c|c|c|c|c|c|}
\hline & & $\begin{array}{l}\text { Kareler } \\
\text { toplamı }\end{array}$ & $\mathrm{sd}$ & $\begin{array}{l}\text { Kareler } \\
\text { ortalamas1 }\end{array}$ & $\mathrm{F}$ & $\mathrm{P}$ & $\begin{array}{l}\text { Fark } \\
\text { Tukey }\end{array}$ \\
\hline \multirow{4}{*}{$\begin{array}{l}\text { Motivasyonsu } \\
\text { zluk }\end{array}$} & Gruplar & 197,962 & 2 & 91,069 & & & \multirow{13}{*}{$\begin{array}{c}\mathrm{FB}> \\
\mathrm{SF}\end{array}$} \\
\hline & aras1 $\ldots$ & & & & & & \\
\hline & Gruplar içi & 2706,507 & 127 & 63,494 & 4,645 & 0,011 & \\
\hline & Total & 2904,469 & 129 & & & & \\
\hline \multirow{3}{*}{$\begin{array}{l}\text { Dişsal } \\
\text { Motivasyon }\end{array}$} & $\begin{array}{l}\text { Gruplar } \\
\text { aras1 }\end{array}$ & 1015,233 & 2 & 208,865 & \multirow{3}{*}{2,789} & \multirow{3}{*}{0,065} & \\
\hline & Gruplar içi & 23117,698 & 127 & 29,240 & & & \\
\hline & Total & 24132,931 & 129 & & & & \\
\hline \multirow{3}{*}{$\begin{array}{l}\text { İçsel } \\
\text { Motivasyon }\end{array}$} & Gruplar & 689,145 & 2 & & \multirow{3}{*}{1,606} & \multirow{3}{*}{0,205} & \\
\hline & aras1 & 27241,778 & 127 & 17,717 & & & \\
\hline & $\begin{array}{l}\text { Gruplar içi } \\
\text { Total }\end{array}$ & 27930,923 & 129 & 6,869 & & & \\
\hline \multirow{3}{*}{ Toplam } & Gruplar & 2771,334 & 2 & & \multirow{3}{*}{2,322} & \multirow{3}{*}{0,102} & \\
\hline & aras1 & 75790,235 & 127 & 452,498 & & & \\
\hline & $\begin{array}{l}\text { Gruplar içi } \\
\text { Total }\end{array}$ & 78561,569 & 129 & 109,390 & & & \\
\hline
\end{tabular}

Tablo 7 incelendiğinde, Felsefe grubu öğrencilerinin akademik motivasyonlarının öğrenim gördükleri bölümlere göre farklılaşıp farklılaşmadığını belirlemek amacıyla yapılan analiz sonuçlarına göre, motivasyonsuzluk alt boyutundaki $\left[\mathrm{F}_{(2-127)}=4,645 ; \mathrm{p}<0,05\right]$ düzeyleri öğrenim gördükleri bölüme göre anlamlı bir farklılık gösterdiği görülmektedir. Ancak felsefe grubu öğrencilerinin dişsal motivasyon alt boyutu $\left[\mathrm{F}_{(2-127)}=2,789 ; \mathrm{p}>0,05\right]$, içsel motivasyon alt boyutu $\left[\mathrm{F}_{(2-127)}=1,606 ; \mathrm{p}>0,05\right]$ ve toplam akademik motivasyon düzeyleri $\left[\mathrm{F}_{(2-127)}=2,322\right.$; p >0,05] öğrenim gördükleri bölüme göre farklılık göstermediği görülmektedir. Varyans analizi sonucunda ortalamalar arasında fark olduğu tespit edilmiştir. Ortaya çıkan farkların hangi 
gruptan kaynaklandığını tespit etmek için "Tukey" testi yapılmıştır. Tukey testi sonuçlarına göre Motivasyonsuzluk alt boyutunda felsefe bölümü öğrencileri ile sosyoloji bölümü formasyon öğrencileri arasında felsefe bölümü öğrencilerinin lehine bir fark görülmektedir $(p<0,05)$.

Felsefe grubu öğrencilerinin, Akademik Motivasyonlarının Yaş Değişkenine Göre anlamlı bir farklılık var mıdır alt problemi kapsamında ANOVA Ve Tukey testi sonuçları tablo 8 'de sunulmuştur.

Tablo 8.

Felsefe Grubu Öğrencilerinin, Akademik Motivasyonlarının Yaş Değişkenine Göre ANOVA Ve Tukey Testi Sonuçları

\begin{tabular}{|c|c|c|c|c|c|c|c|}
\hline & & $\begin{array}{l}\text { Kareler } \\
\text { toplamı }\end{array}$ & sd & $\begin{array}{c}\text { Kareler } \\
\text { ortalamas1 }\end{array}$ & $\mathrm{F}$ & $P$ & $\begin{array}{c}\text { Fark } \\
\text { Tukey }\end{array}$ \\
\hline & Gruplar & 197,962 & 2 & & & & \\
\hline Motivasyons & aras1 & 2706,507 & 127 & 91,069 & 4,645 & 0,011 & $31-40$ \\
\hline uzluk & $\begin{array}{l}\text { Gruplar içi } \\
\text { Total }\end{array}$ & 2904,469 & 129 & 63,494 & & & $\begin{array}{c}> \\
21-30\end{array}$ \\
\hline Dissal & Gruplar & $\begin{array}{c}1015,233 \\
23117698\end{array}$ & $\begin{array}{c}2 \\
127\end{array}$ & 208865 & 780 & 0065 & \\
\hline Motivasyon & $\begin{array}{l}\text { Gruplar içi } \\
\text { Total }\end{array}$ & 24132,931 & 129 & 29,240 & & & \\
\hline İcsel & Gruplar & $\begin{array}{c}689,145 \\
27241778\end{array}$ & $\begin{array}{c}2 \\
127\end{array}$ & & 1606 & $0 \cap 05$ & \\
\hline Motivasyon & $\begin{array}{l}\text { Gruplar içi } \\
\text { Total }\end{array}$ & 27930,923 & 129 & 6,869 & 1,000 & $0,20 J$ & \\
\hline Toplam & $\begin{array}{l}\text { Gruplar } \\
\text { aras1 } \\
\text { Gruplar içi } \\
\text { Total }\end{array}$ & $\begin{array}{c}2771,334 \\
75790,235 \\
78561,569\end{array}$ & $\begin{array}{c}2 \\
127 \\
129\end{array}$ & $\begin{array}{l}452,498 \\
109,390\end{array}$ & 2,322 & 0,102 & \\
\hline
\end{tabular}

Tablo 8 incelendiğinde, Felsefe grubu öğrencilerinin akademik motivasyonlarının yaş değişkenine göre farklılaşıp farklılaşmadığını belirlemek amacıyla yapılan analiz sonuçlarına göre, motivasyonsuzluk alt boyutundaki $\left[\mathrm{F}_{(2-127)}=4,645 ; \mathrm{p}<0,05\right]$ düzeylerinin yaş değişkenine göre anlamlı bir farklılık gösterdiği görülmektedir. Ancak felsefe grubu öğrencilerinin dışsal motivasyon alt boyutu $\left[\mathrm{F}_{(2-127)}=2,789 ; \mathrm{p}>0,05\right]$, içsel motivasyon alt boyutu $\left[\mathrm{F}_{(2-127)}=1,606\right.$; $\mathrm{p}>0,05]$ ve toplam akademik motivasyon düzeylerinin $\left[\mathrm{F}_{(2-127)}=2,322 ; \mathrm{p}>0,05\right]$ yaş değişkenine göre farklılık göstermediği görülmektedir. Tukey testi sonuçlarına göre Motivasyonsuzluk alt boyutunda 31-40 yaş grubu ile 21-30 yaş grubu arasında, 31-40 yaş grubunun lehine bir fark görülmektedir $(\mathrm{p}<0,05)$.

Felsefe grubu öğrencilerinin, Sorgulama Becerilerinin Cinsiyet Değişkenine Göre anlamlı bir farklılık var mıdır alt problemi kapsamında T- testi sonuçları tablo 9'da sunulmuştur.

Tablo 9.

Felsefe Grubu Öğrencilerinin, Sorgulama Becerilerinin Cinsiyet Değişkenine Göre T- Testi Sonuçları

\begin{tabular}{llllllll}
\hline Faktörler & Cinsiyet & $\mathrm{N}$ & $\overline{\mathrm{X}}$ & $\mathrm{Ss}$. & $\mathrm{df}$ & $\mathrm{t}$ & $\mathrm{p}$ \\
\hline Bilgi Edinme & 1.Kadın & 101 & 24,851 & 3,080 & 128 & 1,603 & 0,485 \\
& 2. Erkek & 29 & 23,827 & 2,854 & & & \\
Bilgiyi Kontrol & 1.Kadın & 101 & 19,089 & 2,764 & 128 & 0,772 & 0,003 \\
Etme & & & & & & & \\
& 2.Erkek & 29 & 18,482 & 3,960 & & & \\
Özgüven & 1.Kadın & 101 & 10,623 & 3,055 & 128 & 0,755 & 0,735 \\
& 2.Erkek & 29 & 11,103 & 2,870 & & &
\end{tabular}


Toplam

1.Kadın 101

$54,564 \quad 7,116$

128

0,751

0,627

Tablo 9 incelendiğinde, Felsefe grubu öğrencilerinin sorgulama becerilerinin cinsiyet değişkenine göre bilgi edinme alt faktöründe $\left.\left[\mathrm{t}_{(128)}=1,603\right) ; \mathrm{p}>0,05\right]$, özgüven alt faktöründe $\left.\left[\mathrm{t}_{(128)}=2,323\right) ; \mathrm{p}>0,05\right]$, ve toplam puanda $\left.\left[\mathrm{t}_{(128)}=0,751\right) ; \mathrm{p}>0,05\right]$ anlamli bir farklıl1k göstermediği görülmektedir. Ancak bilgiyi kontrol etme alt faktöründe $\left.\left[\mathrm{t}_{(128)}=0,772\right) ; \mathrm{p}<0,05\right]$ cinsiyet değişkenine göre kadın öğrencilerin lehine anlamlı bir farklılık olduğu görülmektedir.

Felsefe grubu öğrencilerinin, Sorgulama Becerilerinin Mezun Olma Değişkenine Göre anlamlı bir farklılık var mıdır alt problemi kapsamında T-testi sonuçları tablo 10' da sunulmuştur.

Tablo 10

Felsefe Grubu Öğrencilerinin, Sorgulama Becerilerinin Mezun Olma Değişkenine Göre T- Testi Sonuçları

\begin{tabular}{|c|c|c|c|c|c|c|c|}
\hline Faktörler & Mezun olma & $\mathrm{N}$ & $\overline{\bar{x}}$ & Ss. & $\mathrm{df}$ & $\mathrm{t}$ & $\mathrm{p}$ \\
\hline \multirow[t]{2}{*}{ Bilgi Edinme } & Öğrenci olma & 70 & 24,27 & 3,29 & 128 & $-1,425$ & 0,282 \\
\hline & Mezun & 60 & 25,03 & 2,71 & & & \\
\hline \multirow[t]{2}{*}{$\begin{array}{l}\text { Bilgiyi Kontrol } \\
\text { Etme }\end{array}$} & $\begin{array}{c}\text { Öğrenci olma } \\
(4 . \text { sinıf })\end{array}$ & 70 & 19,07 & 3,13 & 128 & 0,471 & 0,972 \\
\hline & .. Mezun & 60 & 18,81 & 2,99 & & & \\
\hline \multirow[t]{2}{*}{ Özgüven } & $\begin{array}{c}\text { Öğrenci olma } \\
\text { (4.sınıf) }\end{array}$ & 70 & 10,27 & 3,13 & 128 & $-1,898$ & 0,119 \\
\hline & .. Mezun & 60 & 11,26 & 2,78 & & & \\
\hline \multirow[t]{2}{*}{ Toplam } & $\begin{array}{c}\text { Öğrenci olma } \\
\text { (4.sinıf) }\end{array}$ & 70 & 53,61 & 7,70 & 128 & $-1,178$ & 0,181 \\
\hline & Mezun & 60 & 55,11 & 6,67 & & & \\
\hline
\end{tabular}

Tablo 10 incelendiğinde, Felsefe grubu öğrencilerinin sorgulama becerilerinin mezun olma değişkenine göre bilgi edinme alt faktöründe $\left[\mathrm{t}_{(128)}=-1,425 ; \mathrm{p}>0,05\right]$, bilgiyi kontrol etme alt faktöründe $\left.\left[\mathrm{t}_{(128)}=0,471\right) ; \mathrm{p}>0,05\right]$, özgüven alt faktöründe [ $\left.\mathrm{t}_{(128)}=-1,898 ; \mathrm{p}>0,05\right]$ ve toplam puanda $\left[\mathrm{t}_{(128)}=-1,178 ; \mathrm{p}>0,05\right]$ anlamlı bir farklılık göstermediği görülmektedir.

Felsefe grubu öğrencilerinin, Sorgulama Becerilerinin Bölüm Değişkenine Göre anlamlı bir farklı1ık var mıdır alt problemi kapsamında ANAVO testi sonuçları tablo 11'de sunulmuştur.

Tablo 11.

Felsefe Grubu Öğrencilerinin, Sorgulama Becerilerinin Bölüm Değişkenine Göre ANOVA Testi Sonuçları

\begin{tabular}{|c|c|c|c|c|c|c|}
\hline & & $\begin{array}{l}\text { Kareler } \\
\text { toplam } 1\end{array}$ & $\mathrm{sd}$ & $\begin{array}{l}\text { Kareler } \\
\text { ortalamas } 1\end{array}$ & $\bar{F}$ & $\mathrm{P}$ \\
\hline \multirow[t]{3}{*}{ Bilgi Edinme } & Gruplar & 19,527 & 2 & 9,763 & \multirow{3}{*}{1,050} & \multirow{3}{*}{0,353} \\
\hline & arasi & 1181,004 & 127 & 9,299 & & \\
\hline & Gruplar içi & 1200,531 & 129 & & & \\
\hline Bilgiyi Kontrol & Gruplar & 9,192 & 2 & 4,596 & \multirow{3}{*}{0,485} & \multirow{3}{*}{0,617} \\
\hline \multirow[t]{2}{*}{ Etme } & aras1 & 1202,532 & 127 & 9,469 & & \\
\hline & Gruplar içi & 1211,723 & 129 & & & \\
\hline \multirow[t]{3}{*}{ Özgüven } & Gruplar & 43,281 & 2 & 21,641 & \multirow{3}{*}{2,440} & \multirow{3}{*}{0,091} \\
\hline & arasi & 1126,296 & 127 & 8,868 & & \\
\hline & Gruplar içi & 1169,577 & 129 & & & \\
\hline
\end{tabular}


Felsefe Grubu Öğrencilerinin Akademik Motivasyonları İle Sorgulama Becerileri Arasındaki İlişkinin İncelenmesi

\begin{tabular}{lllllll}
\multirow{3}{*}{ Toplam } & Gruplar & 75,400 & 2 & 37,700 & & \\
& aras1 & 6722,293 & 127 & 52,931 & 0,712 & 0,492 \\
& Gruplar içi & 6797,692 & 129 & & & \\
\hline & Total & & & & & \\
\hline
\end{tabular}

Tablo 11 incelendiğinde, Felsefe grubu öğrencilerinin sorgulama becerilerinin öğrenim gördükleri bölümlere göre farklılaşıp farklılaşmadığını belirlemek amacıyla yapılan analiz sonuçlarına göre, bilgi edinme alt faktöründeki $\left[\mathrm{F}_{(2-127)}=1,050 ; \mathrm{p}>0,05\right]$, bilgiyi kontrol etme alt faktöründeki $\left[\mathrm{F}_{(2-127)}=0,485 ; \mathrm{p}>0,05\right]$, özgüven alt faktöründeki $\left[\mathrm{F}_{(2-127)}=2,440 ; \mathrm{p}>0,05\right]$, ve toplam $\left[\mathrm{F}_{(2-127)}=0,712 ; \mathrm{p}>0,05\right]$, sorgulama becerileri puanlarının öğrenim gördükleri bölüme göre anlamlı bir farklılık göstermediği görülmektedir. Felsefe grubu öğrencilerinin, Sorgulama Becerilerinin Yaş Değişkenine Göre anlamlı bir farklılık var mıdır alt problemi kapsamında ANAVO testi Ve varyans analizi sonucunda ortalamalar arasında fark olduğu tespit edilmiştir. $\mathrm{Bu}$ farkın hangi gruplardan kaynaklandığını tespit etmek için Dunnett-T3 testi yapılmıştır. Sonuçlar tablo 12'de sunulmuştur.

Tablo 12.

Felsefe grubu öğrencilerinin, Sorgulama Becerilerinin Yaş Değişkenine Göre ANAVO Ve Dunnett-T3 testi sonuçları

\begin{tabular}{|c|c|c|c|c|c|c|c|}
\hline & & $\begin{array}{l}\text { Kareler } \\
\text { toplamı }\end{array}$ & $\mathrm{sd}$ & $\begin{array}{l}\text { Kareler } \\
\text { ortalamas1 }\end{array}$ & $\mathrm{F}$ & $\mathrm{P}$ & $\begin{array}{l}\text { Fark } \\
\text { Dunn } \\
\text { ett-T3 }\end{array}$ \\
\hline Bilgi Edinme & $\begin{array}{l}\text { Gruplar } \\
\text { aras1 } \\
\text { Gruplar içi } \\
\text { Total }\end{array}$ & $\begin{array}{l}73,727 \\
1126,804 \\
1200,531\end{array}$ & $\begin{array}{l}3 \\
126 \\
129 \\
\end{array}$ & $\begin{array}{l}24,576 \\
8,943\end{array}$ & 2,748 & 0,046 & $\begin{array}{c}31 / 40 \\
> \\
21 / 30\end{array}$ \\
\hline $\begin{array}{l}\text { Bilgiyi } \\
\text { Kontrol Etme }\end{array}$ & $\begin{array}{l}\text { Gruplar } \\
\text { arasi } \\
\text { Gruplar içi } \\
\text { Total }\end{array}$ & $\begin{array}{l}70,131 \\
1141,592 \\
1211,723\end{array}$ & $\begin{array}{l}3 \\
126 \\
129\end{array}$ & $\begin{array}{l}23,377 \\
9,060\end{array}$ & 2,580 & 0,056 & $\begin{array}{c}21 / 30 \\
> \\
31 / 40 \\
31 / 40 \\
> \\
41 / 50\end{array}$ \\
\hline Toplam & $\begin{array}{l}\text { Gruplar } \\
\text { aras1 } \\
\text { Gruplar içi } \\
\text { Total }\end{array}$ & $\begin{array}{l}454,746 \\
6342,946 \\
6797,692\end{array}$ & $\begin{array}{l}3 \\
126 \\
129\end{array}$ & $\begin{array}{l}151,582 \\
50,341\end{array}$ & 3,011 & 0,033 & $\begin{array}{c}31 / 40 \\
> \\
21 / 30 \\
41 / 50\end{array}$ \\
\hline
\end{tabular}

Tablo 12 incelendiğinde, Felsefe grubu öğrencilerinin sorgulama becerilerinin yaş değişkenine göre farklılaşıp farklılaşmadığını belirlemek amacıyla yapılan analiz sonuçlarına göre, bilgi edinme alt faktöründeki $\left[\mathrm{F}_{(3-126)}=2,748 ; \mathrm{p}<0,05\right]$, özgüven alt faktöründeki $\left[\mathrm{F}_{(3-}\right.$ $\left.{ }_{126}=2,825 ; \mathrm{p}<0,05\right]$ ve toplam $\left[\mathrm{F}_{(3-126)}=3,011 ; \mathrm{p}<0,05\right]$ sorgulama becerileri puanlarının yaş değişkenine göre anlamlı bir farklılık gösterdiği görülmektedir. Ancak bilgiyi kontrol etme alt faktöründeki $\left[\mathrm{F}_{(3-126)}=2,580 ; \mathrm{p}>0,05\right]$ sorgulama becerileri puanlarının yaş değişkenine göre farklılaşmadığı görülmektedir. Dunnett-T3 testi sonuçlarına göre bilgi edinme alt faktöründe 3140 yaş grubu ile 21-30 yaş grubu arasında 31-40 yaş grubunun lehine bir fark görülmektedir. Bilgiyi kontrol etme alt faktöründe 21-30 yaş grubu ile 31-40 yaş grubu arasında 21-30 yaş grubu lehine anlamlı bir farklılık görülmektedir. Aynı zamanda 31-40 yaş grubu ile 41-50 yaş grubu arasında 31-40 yaş grubu lehine bir fark görülmektedir. Özgüven alt faktöründe 31-40 yaş grubu ile 21-30 yaş grubu arasında 31-40 yaş grubu lehine anlamlı bir farklılık görülmektedir. Toplam puana bakıldığında ise 31-40 yaş grubu ile 21-30 ve 41-50 yaş grupları arasında 31-40 yaş grubu lehine bir farkl11ık görülmektedir. 


\section{Tartışma / Sonuç ve Öneriler}

Araştırmadan elde edilen sonuca göre felsefe grubu öğrencilerinin, bilgi edinme, bilgiyi kontrol etme ve özgüven alt faktörlerine ilişkin görüşlere "çoğunlukla" katıldıkları görülmektedir. Felsefe grubu öğrencilerinin sorgulama becerileri genel ortalama puanları incelendiğinde sorgulama becerilerinin iyi düzeyde olduğu görülmektedir. Bu sonuç Engin'in (2009) öğretmen adayları üzerine yaptığı çalışma sonucuyla paralellik göstermektedir. Sorgulama sürecinde öğretmen rolü oldukça önemlidir (Wu ve Hsieh, 2006). Öğretmenler sorgulamaya dayalı öğrenme stratejilerini etkili bir şekilde uyguladıklarında öğrencilerin sorgulama becerilerini ve akademik başarılarını arttırabilecekleri belirtilmiştir (Balım, İnel ve Evrekli, 2008). Bu bağlamda Felsefe grubu öğrencilerinin sorgulama becerilerinin yüksek olması öğretmenlerin derslerinde sorgulama temelli öğretim uygulamalarına etkili bir şekilde yer verdiklerini düşündürebilir. Bunun yanı sıra Felsefe grubu öğrencilerinin günümüz eğitim anlayışının hedefleri arasında yer alan "sorgulama tabanlı öğretim" uygulamalarını benimsedikleri ve geleneksel eğitim anlayışından uzaklaştıkları düşünülebilir.

Felsefe grubu öğrencilerinin, AMÖ ölçeğinin motivasyonsuzluk alt boyutuna ilişkin görüşleri "hiç uymuyor" düzeyinde kabul ettikleri görülmektedir. Ancak dişsal motivasyon, içsel motivasyon alt boyutuna ve toplam puana ilişkin görüşleri "çok uyuyor" düzeyinde kabul ettikleri görülmektedir. Felsefe grubu öğrencilerinin akademik motivasyonlarının genel ortalama puanları incelendiğinde akademik motivasyon düzeylerinin iyi düzeyde olduğu görülmektedir. Araştırma sonuçları Gömleksiz ve Serhatlığlu'nun (2013) öğretmen adaylarıyla yaptıkları çalışmayla paralellik göstermektedir. Alan yazında pek çok araştırma motivasyon ile akademik başarı arasında pozitif bir ilişki olduğunu ortaya koymuştur. Başka bir değişle öğrencilerin akademik performanslarını harekete geçirmede motivasyon önemli bir unsurdur (Afzal ve diğerleri, 2010; Peklaj-Levpušček, 2006). Felsefe grubu öğrencilerinin akademik motivasyon düzeylerinin iyi düzeyde çıkması araştırma sonucun diğer araştırma sonuçlarıyla paralelik gösterdiğini ortaya koymuştur. Gürşimşek (2002) yaptı̆̆ 1 çalışmada öğretmen adaylarına öğrenme becerisi kazandırmanın yanında, öğrenmeye ilişkin beceri ve istekliliğin de arttırılmasının önemli olduğu sonucuna varmıştır. Bu durum öznel iyi oluşa dikkat çekmektedir. Öznel iyi oluş bireyin içinde bulunduğu yaşamı değerlendirmesi ve yargıda bulunmasıdır. Öznel iyi oluşu arttırmak için bireylerin içsel ve dışsal motivasyona sahip olmalarının önemli olduğunu belirtmiştir (Eryılmaz, 2010). Öğrencilerin başarılı olma gereksinimi, okumaya ve öğrenmeye ilgisi, kendisine bir amaç belirleyip belirlememesi, öğrenebilme konusunda kendine ilişkin yeterlilik algısı ve neden öğrendiğine ilişkin bilişlerin tümü güdülenme düzeyini etkileyen faktörlerdir (Bozanoğlu, 2005). Bu faktörlerin öğrenciler için okullarda verilen eğitim kapsamında geliştirilmesi, iyileştirilmesi ve önemli görülmesi öğrencilerin gelecek yaşantılarına daha sağlıklı adım atmalarına katkı sağlayabilir. Çünkü öğrencilerin, okullarda sunulan eğitim yaşantılarından ne kadar memnun oldukları, kendilerine sunulan yaşantıların onların gelecek yaşamlarına yönelik amaç, ihtiyaç ve beklentilerinin ne kadarının karşılandığı öğrencilerin kişilik oluşumları ve akademik başarıları üzerinde oldukça etkili olduğu belirtilmiştir (İlğan ve diğerleri, 2015).Bu bağlamda okullarda sunulan eğitim yaşantılarının Felsefe grubu öğrencilerinin amaç, ihtiyaç ve beklentilerini çoğunlukla karşıladıkları düşünülebilir.

Bulgular sonucunda Felsefe grubu öğrencilerinin akademik motivasyonları ile sorgulama becerileri arasında "motivasyonsuzluk" boyutu ile "bilgi edinme" ve "özgüven" faktörleri arasında negatif yönlü düşük düzeyli bir ilişki olduğu görülmektedir. "Dışsal motivasyon" boyutu ile "bilgi edinme" ve "bilgiyi kontrol etme" faktörleri arasında pozitif yönlü düşük düzeyli bir ilişki olduğu görülmektedir. "İçsel motivasyon" boyutu ile "bilgi edinme", "bilgiyi kontrol etme" ve "özgüven" faktörleri arasında ise pozitif yönlü ancak düşük düzeyli bir ilişki olduğu tespit edilmiştir. Motivasyon öğrencilerin öğrenme süreci içerisindeki öğrenme tutumlarının oluşmasında önemli bir faktördür (Afzal ve diğerleri, 2010). Öğrencilerin motivasyonlarının pozitif yönde olması yüksek düzeyde öğrenmeye, yaratıcılığa, üst bilişsel farkındalığın ve eleştirel düşünme becerilerinin gelişmesine neden olur (Gömleksiz ve Serhatlığlu, 2013). Bu bağlamda felsefe grubu öğrencilerinin akademik motivasyonları ile sorgulama becerileri arasındaki ilişkinin düşük düzeyli çıkması, öğrencilerin sorgulama 
becerilerinin gelişmesi için gerekli olan düşünce alt yapısına yeteri kadar sahip olmadıkları ve bu alt yapıyı sağlayacak olan psikolojik iyi olma durumunun eksik olduğu söylenilebilir.

Felsefe grubu öğrencilerinin akademik motivasyonlarının cinsiyet değişkenine göre anlamlı bir farklılık göstermediği görülmektedir. Bu sonuç Rusillo ve Arias (2004) ile Yurt ve Bozer'in (2015) yaptıkları çalışma sonucu ile paralellik göstermektedir. Buna karşın Eymur ve Geban'ın (2011) kimya öğretmeni adaylarıyla yaptıkları çalışmada ve Küçükosmanoğlu'un (2015) müzik öğretmeni adayları ile yaptığı çalışmada öğrencilerin akademik motivasyon düzeyleri arasında cinsiyet değişkenine göre anlamlı bir farklılık olduğu tespit edilmiştir. Yapılan bu çalışmaların sonuçlarının cinsiyet değişkenine göre farklılık göstermesinin pek çok nedeni olabilir; kültürel farklılıklar, öğrencilerin yaşı, yaşanılan çevre koşulları, sosyoekonomik ve kültürel durum, okulun fiziki ve kültürel yapısı, okulun bulunduğu şehir, annebabanın eğitim durumu, evde bulunan çocuk sayısı, geleceğe yönelik beklentiler bunlardan bazılarıdır. $\mathrm{Bu}$ gibi nedenlere bağlı olarak farklı sonuçlara ulaşılabileceği gözönünde bulundurulabilir.

Araştırma sonucuna göre Felsefe grubu öğrencilerinin akademik motivasyonlarının mezun olma değişkenine göre anlamlı bir farklılık göstermediği tespit edilmiştir. Bu bağlamda Felsefe grubu öğrencilerinin üniversite öğrenimi süresince karşı karşıya kaldıkları durum ve ortamlarda motivasyon düzeylerinde farklılık oluşturabilecek nitelikte bir değişimin olmadığı söylenebilir. Aynı zamanda mezun olan öğrencilerin de karşı karşıya kaldıkları durum ve ortamlarda motivasyon düzeylerinde farklılık yaratacak bir değişimin olmadığı söylenebilir. Buna karşın Eymur ve Geban (2011) ile Gürşimşek'in (2002) öğretmen adayları ile yaptıkları çalışmalarda ve Küçükosmanoğlu'nun (2015) müzik öğretmeni adaylarıyla yaptığı çalışmada öğrencilerin akademik motivasyon düzeyleri arasında mezun olma değişkenine göre anlamlı bir farklılık olduğu tespit edilmiştir. Öğrencilerin akademik motivasyonlarının mezun olma değişkenine göre karşılaştırıldığı çalışmaların sonuçlarında farklılık olduğu tespit edilmiştir. Bu sonuçlar ışığında araştırmanın gerçekleştirildiği örneklem grubunun bölüme karşı isteklilik hali, akademik çalışmalara yönelik heyecanı ve başarılı bir eğitimci olma isteklerinin hala devam ettiği düşünülebilir. Öğrenciler eğitim gördükleri bölümün iş bulma imkânı açısından kısıtlı olduğunun bilincindedirler. Ancak bu olumsuzluklara rağmen bölüme karşı motive olmalarında her hangi bir düşüş yaşanmadığı sonuçlar ışığında değerlendirilebilir.

Araştırma bulgularına göre Felsefe grubu öğrencilerinin akademik motivasyonlarının öğrenim gördükleri bölüme göre anlamlı bir farklılık göstermediği tespit edilmiştir. Ancak Felsefe grubu öğrencilerinin motivasyonsuzluk alt boyutundaki düzeyleri öğrenim gördükleri bölüme göre anlamlı bir farklılık olduğu tespit edilmiştir. Bu farkın felsefe bölümü öğrencileri ile sosyoloji bölümü formasyon öğrencileri arasında felsefe bölümü öğrencilerinin lehine bir fark olduğu tespit edilmiştir. Diğer bir değişle Felsefe Bölümü öğrencilerinin diğer bölümlere göre akademik motivasyonlarının daha düşük olduğu tespit edilmiştir. Bu sonuç Gömleksiz ve Serhatlığlu' nun (2013) öğretmen adayları üzerine yaptıkları çalışmada motivasyonsuzluk alt boyutunda bölüme göre farklılık olduğu sonucu ile paralellik göstermektedir. Başarılı bir meslek sahibi olarak mezun olma beklentisi öğrencilerin akademik motivasyonunun yanı sıra akademik başarısını da arttıran bir etken olduğu belirtilmiştir (Domene ve diğerleri, 2011). Aynı zamanda geleceğe yönelik iyimser beklentilerin tüm motivasyon türlerinde olumlu yönde etkili olduğu belirlenmiştir (Vallerand ve diğerleri, 1992). Buna karş̧n Lisans mezunu öğrencilerin öğretmen olabilmek için Kamu Personeli Seçme Sınavı'ndan (KPSS) yüksek puan alma zorunluluğu, kontenjanların düşük sayıda olması ve pedagojik formasyon sertifikası alan öğretmen adaylarının sayılarının gün geçtikçe artması öğretmen adaylarında 'kaygı' oluşmasına neden olmakta ve öğretmenlik mesleğine yönelik tutumlarını olumsuz yönde etkilenmektedir (Demircioğlu ve Özdemir, 2014). Bu bağlamda felsefe bölümü öğrencilerinin akademik motivasyon düzeylerinin bu denli düşük olması diğer bölümlere göre atanma oranın düşük olmasına bağlanabilir.

Araştırmadan elde edilen bulgulara göre Felsefe grubu öğrencilerinin akademik motivasyonlarının yaş değişkenine göre farklılık göstermediği tespit edilmiştir. Ancak felsefe grubu öğrencilerinin Motivasyonsuzluk alt boyutundaki düzeyleri yaş değişkenine göre farklılık 
gösterdiği tespit edilmiştir. Bu farkın 31-40 yaş grubu ile 21-30 yaş grubu arasında, 31-40 yaş grubunun lehine bir fark olduğu tespit edilmiştir. Sınıf düzeyi arttıkça öğrencilerin motivasyon düzeylerinin azaldığı belirtilmiştir (İlğan ve diğerleri, 2015). Bu bağlamda 31-40 yaş grubu öğrencilerinin düşük akamedik motivasyon düzeyine sahip olmaları devam eden akademik çalışmalara ve iş hayatında yaşadıkları bıkkınlık ile açıklanabilir.

Felsefe grubu öğrencilerinin, sorgulama becerilerinin cinsiyet değişkenine göre anlamlı bir farklılık göstermediği sonucuna ulaşılmıştır. Bu sonuç Yılmaz ve Karamustafaoğlu'nun (2015) öğretmen adayları üzerine yaptıkları çalışmanın sonucu ile paralellik göstermektedir. Araştırmanın sonucuna göre Felsefe grubu ögrencilerinin, sorgulama becerilerinin mezun olma değişkenine göre anlamlı bir farklılık göstermediği tespit edilmiştir. Bu sonuç Yılmaz ve Karamustafaoğlu'nun (2015) öğretmen adayları üzerine yaptıkları çalışma sonucu ile paralellik göstermektedir. Araştırma sonucuna göre Felsefe grubu öğrencilerinin sorgulama becerilerinin öğrenim gördükleri bölüme göre anlamlı bir farklılık göstermediği görülmektedir. Bu sonuç Karademir'in (2013) öğretmen adayları üzerine yaptıkları çalışma ile paralellik göstermektedir.

Araştırmadan elde edilen diğer bir sonucuna göre Felsefe grubu öğrencilerinin sorgulama becerilerinin yaş değişkenine göre anlamlı bir farkl11ık gösterdiği tespit edilmiştir. Bu farkın 31-40 yaş grubu ile 21-30 ve 41-50 yaş grupları arasında 31-40 yaş grubu lehine bir farklılık olduğu tespit edilmiştir. Sorgulayan birey çevresindeki olay ve olguları analiz ederek öğrenmelerini anlamlı hale getiren, bilginin dayanaklarını ve güvenirliğini sorgulayan, farklı bakış açılarını değerlendiren, düşünme üzerine düşünen bireylerdir (Güleryürek, 2008). Bu bağlamda 31-40 yaş grubu öğrencilerinin sorgulama becerilerini geliştirecek eğilimlere daha fazla yöneldikleri düşünülebilir.

Sonuç olarak Felsefe grubu öğrencilerinin akademik motivasyonlarının ve sorgulama becerilerinin iyi düzeyde olduğu belirlenmiştir. Bu iki değişken arasında düşük düzeyde bir ilişki olduğu tespit edilmiştir. Felsefe grubu öğrencilerinin akademik motivasyonları cinsiyet, bölüm, mezun olma ve yaş değişkenlerine göre anlamlı bir farklılık göstermemektedir. Aynı zamanda felsefe grubu öğrencilerinin sorgulama becerileri cinsiyet, mezun olma, bölüm değişkenlerine göre anlamlı bir farklılık göstermemektedir. Ancak Felsefe grubu öğrencilerinin sorgulama becerileri yaş değişkenine göre anlamlı bir farklılık göstermektedir.

Alan yazınına bakıldığında akademik motivasyon ile sorgulama becerilerinin bir arada ele alınarak incelendiği bir araştırma ile karşılaşılmamıştır. Bu nedenle birbirlerini anlamlı bir biçimde etkilediği düşünülen bu iki değişkenin birlikte ele alındığı farklı çalışmalarla bu konu çok boyutlu ve derinlemesine incelenebilir. Bu bağlamda ileride yapılacak olan araştırmalarda farklı veri toplama tekniklerinin (gözlemler, görüşmeler, deneysel vb.) ve farklı veri kaynaklarının (öğretmenler, öğretim elemanları, okul müdürleri, farklı bölümlerde ve mezun olma kademelerinde öğrenim gören öğrenciler) kullanıldığı araştırmalar yapılabilir. Ayrıca akademik motivasyon sadece üniversitelerde öğrenim gören öğrencilerin değil daha alt kademelerde öğrenim gören öğrencilerin de akademik performansının önemli bir belirleyicisidir. $\mathrm{Bu}$ nedenle, benzer araştırmalar ilköğretim ve ortaöğretim kademelerindeki öğrenciler üzerinde de yapılabilir. Bu çalışmada Cinsiyet, yaş, mezun olma ve öğrenim görülen bölüm değişkenleri ele alınmıştır. İleride yapılacak olan çalışmalarda ise farklı değişkenler ele alınarak durum tespiti yapılabilir. Motivasyon düzeyi ve sorgulama becerisi yüksek bireyler yetiştirebilmek adına gerek sınıf içi uygulamalarda gerekse ders kitaplarında öğrencilerin motivasyon düzeyini arttırırken sorgulama becerilerini de geliştirecek etkinliklere daha çok yer verilebilir. Öğretmenler, öğrencilerinin ilgisini çekebilecek, derse ve okula karşı merak uyandıracak, fikirlerini açıkça ifade edebilecekleri ve düşüncelerini irdeleyebileceği serbest bir öğrenme ortamı oluşturmalıdırlar. Öğrencilerin bu sayede kendilerini güvende hissetmeleri sağlanabilir. Ders kitapları öğrencilerin soru sorma ve sorgulama becerilerini geliştirecek şekilde düzenlenmelidir. Ders kitapları yetersiz kaldığında alternatif etkinlikler düzenlenebilir. Öğrencilerine bu doğrultuda özgün materyaller hazırlatabilir. $\mathrm{Bu}$ şekilde öğrencilerini öğrenme-öğretme sürecine dâhil ederek motivasyonlarını arttırabilir. Öğrencilerinin yaptıkları etkinlikleri değerlendirirken öz-değerlendirme yapmalarını isteyerek bilgilerini sorgulamalarını sağlayabilir. Öğrencileri eğlendirirken-düşündüren bir ders planı tasarlanabilir. 
Sonuç olarak araştırmadan elde edilen bulgulara göre Felsefe grubu öğrencilerinin akademik motivasyon ve sorgulama becerisi düzeylerinin "iyi” düzeyde olduğu tespit edilmiştir. Felsefe grubu öğrencilerinin akademik motivasyonları ile sorgulama becerileri arasında anlamlı bir ilişki bulunmuştur. Felsefe grubu öğrencilerinin akademik motivasyon ve sorgulama becerisi düzeyleri arasında cinsiyet, bölüm değişkeni, bölüm ve yaş değişkenlerine göre anlamlı bir farklılık göstermezken sorgulama becerisi düzeyleri arasında yaş değişkenine göre anlamlı bir farklılık gösterdiği tespit edilmiştir. Bu sonuçların alan yazındaki çalışmalarla paralellik gösterdiği tespit edilmiştir. Birbirini anlamlı bir şekilde etkilediği görülen bu değişkenlerin öğrencilerin akademik başarılarını arttırdığı, derse yönelik olumlu tutum geliştirdiği, bilimsel süreç becerilerinin ve bilimsel işlem becerilerinin gelişiminde etkili olduğu ortaya çıkarılmıştır. Eğitim alanında oldukça önemli görülen bu değişkenlerin üzerinde yoğunlaşılması gerekmektedir. Öğretmen ve öğretmen adaylarına öğretme-öğrenme sürecinde bu değişkenlerin ne kadar önemli olduğu ile ilgili bir eğitim verilebilir. Öğretmen adaylarının bölümleri ile olumsuz imkanlardan haberdar olmalarına rağmen akademik motivasyon ve sorgulama becerilerinin iyi düzeyde çıkmasının nedenlerini daha derinlemesine irdelemek için nitel desenli çalışmalar yapılabilir. 4. Sınıf öğrencilerinin motivasyonsuzluk düzeylerinin daha yüksek çıkmasının nedenleri üzerinde durulmalı ve bu nedenleri ortaya çıkaracak çalışmalar yapılmalıdır. Hangi öğretim kademesinde olursa olsun öğretmenlerin derslerinde uyguladıkları öğretim yöntem ve teknikleri, öğrenme stratejileri öğrencilerinin motivasyonlarını arttırıcı ve sorgulamaya dayalı öğretime yönelik olmalıdır.

\section{Kaynaklar}

Akça, D. (2014). Coğrafya öğretiminde coğrafi sorgulama becerisinin öğrenci başarısına, tutum ve kalıcılığa etkisi (Yayımlanmış yüksek lisans tezi). Konya Selçuk Üniversitesi, Eğitim Bilimleri Enstitüsü, Konya.

Aldan Karademir, Ç. ve Saraçaloğlu, A. S. (2014). Sorgulama Becerileri Ölçeği'nin geliştirilmesi: Geçerlik ve güvenirlik çalışması. Asya Öğretim Dergisi, 1(2), 56-65.

Arseven, A., Dervişoğlu, F. M. ve Arseven, İ. (2015). Tarih öğretmen adaylarının sorgulama becerileri ile eleştirel düşünme eğilimleri arasındaki ilişki. The Journal of Academic Social Science Studies, 32(3), 171-185.

Aydın, O. (2004). Güdüler ve duygular. E. Özkalp (Yay. haz.). Davranış Bilimine Giriş, içinde (ss. 196-208). Eskişehir: Anadolu Üniversitesi Açıköğretim Fakültesi Yayınları. Yayın No:75.

Babadoğan, C. ve Gürkan, T. (2002). Sorgulayıcı öğretim stratejisinin akademik başarıya etkisi. Eğitim Bilimleri ve Uygulama Dergisi, 1(2), 147-160.

Balım, G.A., İnel, D. ve Evrekli, E. (2008). Fen öğretiminde kavram karikatürü kullanımının öğrencilerin akademik başarılarına ve sorgulayıcı öğrenme becerileri algılarına etkisi. Illkögretim Online, 7(1), 188-202.

Barutçugil, İ. (2004). Stratejik insan kaynakları yönetimi. İstanbul: Kariyer Yayınları.

Bedir, T. ve Duman, B. (2017). Öğretmen adaylarının sorgulama becerilerinin incelenmesi. Turkish studies, Literature and History of Turkish or Turkic, 12/18, 105-120.

Bozanoğlu, İ. (2005). Bilişsel davranışçı yaklaşıma dayalı grup rehberliğinin güdülenme, benlik saygısı, başarı ve sınav kaygısı düzeylerine etkisi. Ankara Üniversitesi Eğitim Bilimleri Fakültesi Dergisi, 38(1), 17-42.

Büyüköztürk, Ş., Kılıç Çakmak, E., Akgün, Ö. E., Karadeniz, Ş. ve Demirel, F. (2013). Bilimsel araştırma yöntemleri. Ankara: Pegem Akademi Yayıncılık.

Clark, M. H. ve Schroth, C. A. (2010). Examining relationships between academic motivation and personality among college students. Learning and Individual Differences, 20(1), 19-24.

Costa, A. (1991). The inquiry strategy. A. Costa (Yay. haz.). Developing minds: A source book for teaching thinking. USA Virginia: Association For Supervision and Curriculum Development. 
Deci, E. L. ve Ryan, R. M. (2000). The 'what' and 'why' of goal pursuits: human needs and the self-determination of behavior. Psychological Inquiry, 1, 227-268.

Deci, E. L., Vallerand, R. J., Pelletier, L. G. ve Ryan, R. M. (1991). Motivation and education: The self-determination perspective. The Educational Psychologist, 26, 325-346.

Deci, E. L. ve Ryan, R. M. (1985). Intrinsic motivation and self-determination in human behavior. New York: Plenum Press.

Demircioğlu, E. ve Özdemir, M. (2014). Fen ve edebiyat fakültesi öğrencilerinin öğretmenlik mesleğine yönelik tutumlarının çeşitli değişkenlere göre incelenmesi. Mersin Üniversitesi Ë̆itim Fakültesi Dergisi, 3(10), 110-122.

Demir, M. K. ve Arı, E. (2013). Öğretmen adaylarının akademik güdülenme düzeylerinin çeşitli değişkenler açısından incelenmesi. Eğitimde Kuram ve Uygulama Dergisi, 9(3), 265279.

Dibiase, W. ve McDonald, J. R. (2015). Science teacher attitudes toward inquiry-based teaching and learning. The clearing house: A Journal of Educational Strategies, Issues and Ideas, (ahead-ofprint), 1-10.

Domene, J. F., Socholotiuk, K. D. ve Woitowicz, L. A. (2011). Academic motivation in postsecondary students: Effects of career outcome expectations and type of aspiration. Canadian Journal of Education, 34(1), 99-127.

Dörnyei, Z. ve Ottó, I. (1998). Motivation in action: a process model of 12 motivation. Working Papers in Applied Linguistics, (4), 43-69.

Emir, S., Hüner, S. ve Uzelli, O. (2012). Sokratik sorgulama yönteminin akademik başar,, eleştirel düşünme ve üstbilişsel farkındalık düzeyleri üzerindeki etkisinin incelenmesi. Erişim adresi: https://www.pegem.net/Akademi/arama_sonuc.aspx?kriter=Bildiri\& kelime $=$ akademik $\% 20 \mathrm{ba} \% \mathrm{C} 5 \% 9$ Far\%C4\%B1

Engin, G. (2009). Sinıf öğretmeni adaylarının sorgulama yaklaşımını algılama ve öğretim becerilerinin araştırılması: Türkiye-Hollanda karşılaş̧ırma çalışması (Yayımlanmamış yüksek lisans tezi). Ege Üniversitesi, Sosyal Bilimler Enstitüsü, İzmir.

Eren, E. (2012). Örgütsel davranış ve yönetim psikolojisi. (13.Bask1). İstanbul: Beta BasımYayım-Dă̆ıtım.

Ersarı, G. Ve Naktiyok, A. (2012). İş gören içsel ve dışsal motivasyon da stresle mücadele tekniklerinin rolü. Atatürk Üniversitesi Sosyal Bilimler Dergisi, 16(1), 81-101.

Eryılmaz, A. (2010). Ergenlerde öznel iyi oluş stratejilerinin kullanımı ile akademik motivasyon arasındaki ilişki. Klinik Psikiyatri Dergisi, 13, 77-84.

Eymur, G. ve Geban, Ö. (2011). An investigation of relationship between motivation and academic achievement of pre-service chemistry teachers. Ë̆itim ve Bilim, 36, 246-255.

Fraenkel, J. R. ve Wallen, N. E. (2009). How to design and evaluate research in education (7th ed.). PA: McGraw-Hill.

Güngör Seyhan, H. (2008). Kimya eğitiminde sorgulamaya dayall öğrenci deneylerinin geliştirilmesi ve sonuçlarının tartışılması (Yayımlanmamış yüksek lisans tezi), Gazi Üniversitesi, Eğitim Bilimleri Enstitüsü, Ankara.

Gürşimşek, I. (2002). Öğretmen adaylarında öğrenmeye ilişkin motivasyonel inançlar ve strateji kullanımı. Muğla Üniversitesi Sosyal Bilimler Dergisi, 8, 135-155.

Gömleksiz, M. N. ve Serhatlığlu, B. (2013). Öğretmen adaylarının akademik motivasyon düzeylerine ilişkin görüşleri. Türkiye Sosyal Araştırmalar Dergisi, 173, 99-127.

İlğan, A., Oğuz, E. ve Yapar, B. (2015). Okul yaşam kalitesine ilişkin alg1 ile akademik motivasyon düzeyi arasındaki ilişkinin incelenmesi. Abant İzzet Baysal Üniversitesi Ĕ̈itim Fakültesi Dergisi, 2(13), 158-176.

İlter, İ. (2013). Sosyal bilgiler dersinde sorgulayıc1- araştırma tabanlı öğrenme modeli: Başarı ve öğrenmede kalıcıllğın incelenmesi. Turkish Studies, 8(12), 591-605.

Karademir, A. Ç. (2013). Öğretmen adaylarının sorgulama ve eleştirel düşünme becerilerinin ögretmen öz-yeterlik düzeyine etkisi (Yayımlanmamış doktora tezi). Adnan Menderes Üniversitesi, Sosyal Bilimler Enstitüsü, Aydın.

Karasar, N. (2000). Bilimsel araştırma yöntemleri. Nobel Yayın Dağıtım: Ankara. 
Karataş, H. (2011). Üniversite ögrrencilerinin epistemolojik inançlari, ögrenme yaklaşimlari ve problem çözme becerilerinin akademik motivasyonu yordama gücü (Yayımlanmış doktora tezi). Yıldız Teknik Üniversitesi Sosyal Bilimler Enstitüsü, İstanbul.

Karataş, H. ve Erden, M. (2012). Akademik motivasyon ölçeğinin dilsel eşdeğerlik, geçerlik ve güvenirlik çalışması. E-Journal of New World Sciences Academy, 7(1).

Kızılarslan, A. (2014). Fen ve teknoloji öğretmen adaylarının sorgulamaya dayalı öğretime ilişkin tutumları. Uluslararası Hakemli Beşeri ve Akademik Bilimler Dergisi, 3(6), 3040.

Küçükosmanoğlu, H. O. (2015). Müzik öğretmeni adaylarinin akademik motivasyon düzeylerinin belirlenmesi üzerine bir çalışma (Konya İli Örneği). Sanat Eğitimi Dergisi, $3(1), 1-21$.

Luthans, F. (1995). Organizational behavior (7thed.). McGraw-Hill Publishing: New York.

MEB, (2004). Tebliğler Dergisi, 67, 2563.

Peklaj, C. ve Levpušček, M. P. (2006). Student motivation and academic success in relation to the quality of individual and collaborative work during a course in educational psychology. 31. Association of Teacher Education in Europe ATTE.

Rienties, B., Tempelaar, D. T., Van den Bossche, P., Gijselaers, W. H. ve Segers, M. (2009). The role of academic motivation in computer-supported collaborative learning. Computers in Human Behavior, 25(6), 1195-1206.

Rusillo, M. T .C. ve Arias, P. F. C. (2004). Gender differences in academic motivation of secondary school students. Electronic Journal of Research in Educational Psychology, 2(1), 97-112.

Ryan, R. M., Kuhl, J. ve Deci, E. L. (1997). Nature and autonomy: Organizational view of social and neurobiological aspects of selfregulation in behavior and development. Development and Psychopathology, 9, 701-728.

Schunk, D. H., Pintrich, P. R. ve Meece, J. (2008). Motivation in education: Theory, research, and application. New Jersey: Prentice Hall.

Stephenson, N. (2010). Introduction to inquiry based learning. Erişim adresi: http://www.teachinquiry.com/index/Introduction.html.

Stripling, B. (2008). Inquiry: Inquiring minds want to know. School Library Media Activities $X X V(1), \quad 50-52 . \quad$ Erişim adresi: www.teachingbooks.net/content/InquiringMinds WantToKnow-Stripling.pdf

Şen, H. C. (2010). Bir öğrenci özellikleri-uygulama etkileşimi çalışması: sorgulama temelli ögretim ve düz anlatım metotlarıyla öğretimin lise öğrencilerinin fizik başarısı üzerindeki etkisi (Yayımlanmamış doktora tezi). Orta Doğu Teknik Üniversitesi, Fen Bilimleri Enstitüsü, Ankara.

TDK, (2017). Sorgulama. Erişim adresi: http://www.tdk.gov.tr/

Tekin, H. (1996). Ĕgitimde ölçme ve değerlendirme. Ankara: Yargı Yayınları.

Vallerand, R. J., Pelletier, L., Blais, M. R., Briere, N. M., Senecal, C. ve Vallieres, E. F. (1993). On the assessment of intrinsic, extrinsic, and amotivation in education: Evidence on the concurrent and construct validity of the academic motivation scale. Educational and Psychological Measurement, 53, 159-172.

Vallerand, R. J., Pelletier, L. G., Blais, M. R. Biere, N. M., Senecal, C. ve Valleries, E. F. (1992). The academic motivation scale: a measure of intrinsic, extrinsic and motivation in education. Educational Psychological Measurement, 52, 1003-1017.

Yıldırım, A. ve Şimşek, H. (2004). Sosyal bilimlerde nitel araştırma yöntemleri. Ankara: Seçkin Yayıncilik.

Yılmaz, Z. ve Karamustafaoğlu, S. (2015). Öğretmen adaylarının sorgulama becerilerinin farklı değişkenler açısından değerlendirilmesi. Dicle Üniversitesi Ziya Gökalp Eğitim Fakültesi Dergisi, 25, 347-363.

Zhu, Z. ve Geelan, D. (2013). Chinese secondary physics teachers' beliefs and instructional decisions in relation to inquiry-based teaching. Electronic Journal of Science Education, 17(2), 1-24. 
Wilkesmann, U., Fischer, H. ve Virgillito, A. (2012). Academic motivation of students - the german case, discussion papers des zentrums für hochschulbildung (vormals zentrum für weiterbildung) Technische Universität Dortmund, ISSN 1863-0294

$\mathrm{Wu}, \mathrm{H}-\mathrm{K}$. ve Hsieh, C-E. (2006). Developing sixth graders' inquiry skills to construct explanations in inquiry-based learning environments. International Journal of Science Education, 28(1), 1289-1313.

\section{Extended Abstract}

\section{Introduction}

Referring to the literature, it isn't seen any research being focused on both the variables of academic motivation and inquiry skills. There fore, in this study, moving from the thought that it is significant to study on both of these variables which affect each other because it is thought to be quite important to reveal the change of philosophy students' academic motivation has an effect on their questioning skills. More over; his study is quite important to find out the types and the levels of the academic motivation that students have and how to overcome the deficiencies which prevent students' inquiry skills and to make suggestions how to develop these skills. As a result of this study, the data we obtain will shed light on further research.

In this study, it is aimed to search the relation betwean the academic motivation and questioning of philosophy students according to different variables. Fort his aim, the questions below are asked:

1. How is the inquiry skills of the philosophy students?

2. How is the academic motivation of the philosophy students?

3. Is there any significant relation between the academic motivation and inquiryskills of the philosophy students?

4. İs there any significant difference in academic motivation of the philosophy students (gender, graduation, department, age)?

5. Is there any significant difference in inquiry skills of the philosophy students (gender, graduation, department, age)?

\section{Method}

In this descriptive study; among survey models, correlational survey model is used to confirm the relation between the academic motivation and the inquiry skills of the philosophy students.

\section{Population and sample}

The population of this study is formed by the senior students of Philosophy Department in a state university and students who study for their initial teacher training in 2016-2017 academic year. The sample of this study is formed by a total of 133 students; 73 of them are senior students of Philosophy Department, 11 of them are the grad students of philosophy studying for their initial teacher training and 49 of them are grad students of Sociology Departmant studying for their teacher training $(104$ women $(\% 78,2), 29$ men $(\% 21,8))$.

\section{Data collection tools}

"Academic Motivation Scale" (1992) being developed by Vallerand and his friends and (Karataş \& Erden, 2011) being adapted to conditions of our country-is used to collect data for our study. Furthermore, "Inquiry Skills Scale" and "Personal Information Form" being developed by Karademir (2013) are also used in this research.

\section{Analysis of data}

In the analysis stage, Kolmogorov-Smirnow Test is applied to find out whether the distribution of data is normal or not. As a result of the test being carried out, it is clearly seen the distribution of data is normal. As the result of Levene Test, it is confirmed that equality of variances is 
prouided $(\mathrm{F}=.651, \mathrm{P}>0.05)$ For this reason, t-test for independent variables, ANOVA test and analysis of Pearson Coefficient of correalation are used according to the reserach questions. 0,05 is accepted as the level of significance.

\section{Arguments / Results and Suggestions:}

As a conclusion, it is confirmed that the level of academic motivation and inquiry skills of Philosophy students is "good" according to the acquired findings. İt is found out that there is a positive relation between the accademic motivation and the inquiry skills of the philosophy students. It is also seen thtat there is a negative and low relation between the elements like "selfconfidence" and "knowledge acquision" with the level of "motivational" among the academic motivation and inquiry skills of the philosophy students. It is clearly seen that there is positive relation between the elements like "knowledge acquisition" and "supervising the knowledge" with the level of "extrinsic motivation". We can also see that there is a positive but a low relation among the elements like "supervising the knowledge" and "self confidence" with the level of "internal motivation". We can't see any difference among the factors such as gender, departments or faculties, and age variable through the academic motivation and inquiry skills of the philosophy students; however, we can see that there is a significant difference among the level of knowledge acquisition according to the age variable. It is also clear that there is a parallelism between these results and the studies in the field of this topic. In this study, it is clearly seen that students has increased their academic success, developed a positive attitude towards their lessons and also improved scientific process skills and processing skills thanks to these variables which affect each other in a significant way. It is quite essential to focus on such variables in the field of education. Teachers and the teacher candidates can be trained about how important these variables are in the teaching learning process. Even though teacher candidates know about the negative possibilities in their deportment, their academic motivation and inquiry skills are at "good level"; so that it can be done a qualitative research to confirm the reasons of this. It should be focused on why the amotivation level of senior students are so high; besides it should be studied on these reasons. No matter which faculty or department teachers educate, the teaching methods-techniques and learning strategres used by teachers should be increased students motivation and also should be appropriate for inquiry-based learning. 